\title{
Assessing the Impact of Electronic Human Resource Management on Creation of Organizational Agility: A Study in the Bushehr Banks, Iran
}

\author{
Fakhriyeh Hamidianpour $^{1}$, Majid Esmaeilpour ${ }^{2} \&$ Habibeh Firoozi $^{3}$ \\ ${ }^{1}$ Assistant professor in Human Resources Management, Persian Gulf University, Bushehr, Iran \\ ${ }^{2}$ Assistant professor in Business Management, Persian Gulf University, Bushehr, Iran \\ ${ }^{3}$ Graduate student of Business Management, Persian Gulf University, Bushehr, Iran \\ Correspondence: Fakhriyeh Hamidianpour, Department of Business Management, Persian Gulf University, \\ Shahid Mahini Street, Bushehr, Zip code: 7516913798. Iran. E-mail: Fakhriyeh_hamidianpour@yahoo.com
}

Received: January 30, 2016 Accepted: March 24, 2016 Online Published: June 21, 2016

doi:10.5539/ass.v12n7p105 URL: http://dx.doi.org/10.5539/ass.v12n7p105

\begin{abstract}
Agility is a series of capabilities and competencies, which can cause survival and growth of the organization in business environment. One of the approaches that help organizations to enhance agility is electronic human resource management (E-HRM) approach. The main objective of the present study is finding an answer for this issue that how one can use E-HRM approach to develop organizational agility. In this study that has been conducted using survey method, after review of foreign and domestic research literature and construction of conceptual model, a questionnaire would be provided and distributed among employees of bank branches of Bushehr City in Iran and finally, collected data from 315 questionnaires would be analyzed using structural equation modeling method. Obtained results from the study confirm the presented conceptual model and indicate that using electronic learning of human resources, electronic payment of human resources, human resources maintenance and electronic performance appraisal of human resources and also electronic human resource management (E-HRM) can affect organizational agility significantly in confidence level of $99 \%$. In addition, effect of variables of Electronic employment of human resources and human resource communications on organizational agility has not been confirmed.
\end{abstract}

Keywords: electronic human resource management (E-HRM), e-learning of human resources, e-payment of human resources, e-performance appraisal of human resource, organizational agility

\section{Introduction}

Today, information technology has influenced in all parts of the organization and even the most important organizational resource that is human resource has been also affected by the technology. Information technology has made organizations have a comprehensive and perfect view to their resources, especially human resources. Using this system, one can increase authorities of employees and give complete and required information to them, so that they can do their best in regard with their organizational tasks (Musakhani et al., 2011). Under current conditions that organizations are facing rapid evolutions and competition, human resource management (HRM) is expected to create value for the organizations. The value creation is for both in and out-organization beneficiaries. Hence, human resource managers should use modern systems in field of human resources and create integration in human resource processes to achieve desired values. Electronic human resource management (E-HRM) can affect all fields of HRM. Survey of human resource counselors indicates that number of organizations used E-HRM has been increased and also, depth of using its information in organizations is being increased (Ardakani et al., 2013). One of the problems for the current organizations is increase in administrative costs and other costs. To decrease the costs, almost all large organizations use E-HRM system. Using this system can be effective for learning, performance appraisal of employees and payment of their rewards and benefits. Through designing and implementing E-HRM system, achievement to organizational targets has been facilitated. HRM can use web technologies to be more flexible, cost-effective, customer-oriented and more strategic (Stone, 2009). Modern organizations define E-HRM as a competitive solution for business that has the ability to create perfect supports for management of all processes, activities, data and required information of human resource management at the organization (Srivastava, 2010). 
Today, many organizations and firms are facing sustainable and increasing and also uncertain competition, which has been intensified as a result of technological innovations, change in market environments and changing needs of customers. Past approaches and solutions have lost their capability and ability for overcoming organizational challenges and contemporary outside environment to an extent and it would be better to replace them with new approaches and perspectives. Hence, one of the ways for answering organizational evolution and change is agility (Farsijani \& Aref nejad, 2011). Agility has been defined as the ability for survival and progress in a very competitive environment with continuous and unpredictable changes through effective rapid response to changes and creating products and services based on customer desire. The origin of formation of agility in the organizations is associated with manufacturing industries. These changes have passed from handicrafts industries to mass production and then to age of quality and then to lean production and currently, they have been changed into agile production (Hosseini et al.., 2011). Information technology is being developed rapidly and there is no doubt that it can affect organizations too. Therefore, agile organizations need developed and flexible information and communication systems, so that they can guarantee certain flow of information due to the problems and have also the ability to cope with changing conditions. In addition, information and communication technologies (ICT) can have deep effect on HRM field and have also changed it in some new aspects (Musakhani et al., 2011).

Clearly, today the main concern of many organizations is the issue of human resource and how to have rapid response and flexibility to environmental changes using information technology (IT) and that how one can develop capabilities of an agile organization using E-HRM? Hence, the main issue of this study is that whether using E-HRM can make the current organizations agile or not? What factors and activities of E-HRM can affect agility of the organization significantly? In this study, the main concern is finding an answer for these questions. The study has reviewed previous studies in relation with the studied subject and has designed a conceptual model that can indicate the relationship of these elements with agility of the organization. Then, required data has been collected to test conceptual model of the research.

\section{Literature Review and Research Background}

\subsection{Electronic Human Resource Management}

Human Resource Management (HRM) is almost new term, because it has become common since 1970s decade. Still many people use more traditional terms to refer to this field such as personnel management, personnel affair management and industrial relations (Dolan \& Schuler, 2009). With the invention of computer and its high computing ability, using the device in the organizations gained many attentions. With the spread of computers, using the device was expanded in all organizational scopes. With the presence of modern information technology and presence of different software and hardware programs, daily tasks of HRM that were time consuming previously with handy methods could change into simple activities (Zare Elmi, 2011). According to Henson (2008), today workforce and technology are considered as heartbeat and set of business tools of human resources. As HRM is undoubtedly the most important unit of every organization for workforce development, information technology is also undoubtedly the empowerment force of HRM to achieve such targets. Survey of human resource counselors indicates that number of organizations used E-HRM has been increased and also, depth of using its information in organizations is being increased (Ruta, 2005). Ruël et al. (2007) have defined E-HRM as a solution for implementation of strategies, policies and HRM methods in the organization through conscious and direct support using web-based canals.

A relatively comprehensive definition has been presented by Strohmeier (2007) for E-HRM. In view of Strohmeier, E-HRM is planning, implementing and using information technology for connecting at least two persons or two groups for purpose of implementing common activities associated with human resources. E-HRM is evolved form of information system of HRM, which is responsible for strategic tasks of it in addition to implement traditional tasks of HRM (Hosseini et al., 2011).

\subsection{Tasks and Concepts of E-HRM}

In Table 1, some tasks and functions of E-HRM have been presented. For example, employees in different geographical regions can work with each other. Internet gives the chance to firms to search for their required talents regardless of geographical limitations.

Musakhani et al. (2011) have conducted a study to present a model for E-HRM in public organizations and have found that E-HRM has the potential to reduce management costs, increase productivity, accelerate response time, improve decision-making and develop customer service. Bissola and Imperator (2014) have conducted a study under the title of assessing this issue that can reorganization chances presented by web technology empower the relationship of human resources or not and that can they result in presenting more transparent policies for personnel management and increase in fairness perception by human resources? They have found in this study 
that there is positive correlation between using E-HRM and perceived fairness of human resources of different departments of the organization. Strohmeier and Kabst (2014) have conducted a study under the title of main organizational factors in acceptance of E-HRM in Europe. Findings of the study on 2336 organizations in 23 European countries indicated that main factors affecting acceptance of E-HRM include form size, type of activity of the organization, regulation and structure of human resources in the organization. In addition, there is a main international difference for its acceptance, which can affect fields of creating innovation in the organization.

Table 1. Tasks and concepts of E-HRM

\begin{tabular}{cl}
\hline Tasks of HRM & Function of E-HRM \\
\hline Job analysis & $\begin{array}{l}\text { Employees in different regions can work with each other in a virtual team using a } \\
\text { computer screen, email and internet. }\end{array}$ \\
$\begin{array}{c}\text { New workforce } \\
\text { employment }\end{array}$ & $\begin{array}{l}\text { Employment advertisement would be propagated in online form, so that applicants can } \\
\text { communicate easily with the organization. }\end{array}$ \\
Training & $\begin{array}{l}\text { Online training gives the chance to people to use it every time and everywhere they are. } \\
\text { Online activities such as online video tests can evaluate capabilities of people in field of } \\
\text { facing work problems, which may be occurred in future. }\end{array}$ \\
Payment system & $\begin{array}{l}\text { Employees can observe relevant information of their salary and benefits and watch them } \\
\text { in different projects. }\end{array}$
\end{tabular}

Source: Provided by authors.

Another study has been conducted by Mehrjoo and Mirmosavi (2014) to investigate the relationship between E-HRM systems and leadership in human resources. Findings of the study indicate that in limit of educational services, there is significant relationship between E-HRM and creating organizational leadership. They have suggested that attitude of all organizational personnel should be changed and wide changes should be also created in educational courses and development of trust in employees and improvement of their performance should be also achieved. Heikkil (2013) has conducted a study to assess effect of E-HRM on multinational organizations in China, which has helped significantly the issue of international strategic management. Obtained results from the study indicated that E-HRM can result in increase in costs, time consumption of administrative tasks and in some cases; it has resulted in decrease in quality of services. The study has mentioned that it should be also noted that the positive and negative effects have been related to China. Another study conducted by Yusliza and Ramayah (2012) has assessed the relationship of E-HRM, facility of using it, perception of its usefulness and its social effects on the attitude of using E-HRM. Obtained results indicated significant relationship between the variables.

Stone et al. (2013) have conducted a study to investigate effective factors in effectiveness and acceptance of electronic employment and selection systems. In fact, the study has found that currently, using amount of e-employment systems is being increased in the organizations. It can be also useful for effectiveness and acceptance of this system in each stage of employment process including (A) job analysis, (b) apply, and (c) pre-employment interviews, (d) interview, (e) decisions for final selection, and (f) evaluation and validation. However, it should be noted that in this process, privacy of people should be considered. Sharon et al. (2014) have conducted a study to investigate mutual effect of leader-member e-communications in psychological empowerment and working outputs of employees. Obtained results from the study indicated that to have proper perception of role of leader in prevailing mental empowerment and positive outputs of work for personnel, they should be involved in their electronic communications. In fact, it is in relationship with making personnel involved in the electronic processes in psychological terms. It means that satisfaction and commitment of employees to their job would be increased, whereby their working outputs and returns would be also empowered.

David et al. (2015) have conducted a study under the title of perception of information exchange in healthcare operations in 173 hospitals of USA. They believe that adaptation in processes of healthcare service supplying is too complicated and difficult. In fact, they have considered 3 important variables in this study including adaptation, vertical integration and social interaction. Finally, they found that using e-communications can create such integration. Malin and Youyi (2015) have conducted a study to evaluate performance of e-government to protect the natural environment in Anhui Province. In this study, three variables of degree of public participation, 
website service quality and public satisfaction have been evaluated using web. Obtained results from the study indicated that 4 cities of 16 cities are in efficient boundary in field of electronic evaluation and all remained ones have acted inefficiently in this field. Hence, e-government operations in Anhui Province should be improved to achieve efficacy.

Candy et al. (2015) have conducted a study under the title of decision making for selecting e-education system. In this study, they have found that when employees have right to choice between old and new systems, they accept a new e-education system. As a result, they found that e-education systems can make users have better and more effective perception of subjects. Dongming et al. (2014) have conducted an empirical study to investigate increase in effectiveness of e-education using an intelligent personal virtual learning environment. In this study on 228 students, they found that personal e-education equipment can increase effectiveness of e-education in terms of satisfaction and self-efficacy criteria of individual.

Antonio Ruiz (2015) has conducted a study under the title of creating a framework for using e-payment. According to the study, one can use web to have easy access to many attractive products and services and many business models on web. Internet business models have emphasis on e-payment. Using e-payment by web is a very complicated issue, since it includes various payment tools such as safe exchange of payment information, receipt and so on. Laura and Jonathan (2014) have conducted a study to investigate effect of electronic financial payments ion crimes. In fact, the main objective of this study has been testing the hypothesis that access to e-payments may increase crime rate. Obtained results from the study indicated that there is a negative and significant correlation between access to e-payment and commitment of economic crimes such as theft. Electronic transactions can reduce occurrence of intentional and noneconomic crimes such as murder. In addition, the technology can increase transactions without paying in cash and prohibiting crimes.

\subsection{Organizational Agility}

The word "agility" means fast, agile and active movement and agility is the ability to move fast and easy (Ganguly et al., 2009) and being able to think rapidly and through an intelligent way. At the current environment, every organization should have the ability to produce at the same time different methods and with short lifetime, redesign of products, changing production methods and ability to show efficient response to changes, so that it can be called as agile organization (Pan \& Nagi, 2009). Agility is the result for being aware of changes in a comprehensive form in both inside and outside environment. Agility has competent capability to use resources to show response to these changes on right time and in a flexible form that can be also done easily by the organization (Braunscheidel \& Suresh, 2009). According to Sharifi and zHuang(1999), agility means ability of every organization for feeling, perceiving and predicting changes of workplace. Such organization should be able to detect environmental changes and consider them as growth and prosperity factors. They have also defined agility as the ability to overcome unexpected challenges to face unpredicted threats of workplace and gaining advantage and benefit from changes as growth and progress opportunities.

\subsection{Features and Main Functions in Organizational Agility}

Main features in agile organizations presented by Tsourveloudis (2003) that can differentiate company are presented in Table 2 .

Sharifi and zhang (1999) believe that agility providing technologies include hardware, tools and equipment of information technology. In expanded manufacturing systems, IT has a main role in integration of manufacturing companies that are dispersed physically. Salami et al. (2013) have conducted a study with the aim of identifying effective factors in organizational agility and ranking them on senior directors of IRIB Iran Broadcasting. Obtained results from the study indicated that Iran Broadcasting Organization is agile from all dimensions and IT and supply chain has highest rank and human resource has the lowest rank in creating agility of the organization. Huang et al. (2012) have conducted a study in regard with how to achieve agility. Regarding this issue that agility has complicated nature and is difficult to understand, they have stated that IT can act as a leverage to achieve organizational agility. Yaghoobi and Rahat Dahmarde (2010) have stated that the best way for survival and success of the organizations is being focused on agility and have conducted a study in regard with identification of effective factors of agility. Participation, information technology, management, skills, workforce learning and accountability, knowledge management, innovation, performance management, human resources management, coordination and organizational structure have been recognized as empowerment factors of organizational agility. Sherehiy et al. (2007) have presented a framework for concept of agility through studying agile manufacturing companies and studying available literature. They have found that flexibility, acceleration, responsibility and change can be characteristics of an agile organization. In addition, many other scholars like John et al. (2001), Sharifi and zhang (1999) have introduced capabilities of organizational agility as 
responsibility, learning, human resource flexibility and innovation. Jang believes that agility can be achieved through codification of 3 main strategies including acceleration, responsibility and activism.

Table 2. Main features of agile organization

\begin{tabular}{cl}
\hline Features & Functions or components \\
\hline Flexibility & $\begin{array}{l}\text { flexible production models, flexible manufacturing systems, flexible personnel practices } \\
\text { and flexible organizational structure, flexible workplace and business strategies }\end{array}$ \\
\hline Responsibility & $\begin{array}{l}\text { Respond to changes in demand and customer demands; Respond to market and business } \\
\text { environment variables and trends; Meet the social and environmental demands; The } \\
\text { adaptation to changing business goals }\end{array}$ \\
\hline Change culture & $\begin{array}{l}\text { Environmental protection for testing, learning and innovation; A positive attitude to } \\
\text { change, new ideas, people and technology; Continuous improvement, learning and } \\
\text { training; Management of changes and changes in corporate responsibility }\end{array}$ \\
\hline Speed & $\begin{array}{l}\text { Learning, work and operations and make changes the minimum possible time; Time } \\
\text { operation, time changes, product, service or product delivery time; learning time and } \\
\text { changing time adaptation and adaptability }\end{array}$ \\
\hline $\begin{array}{c}\text { Integration and } \\
\text { complexity }\end{array}$ & $\begin{array}{l}\text { Integration of various technologies, skills, competencies; Low complexity of the } \\
\text { relationship between structure; Speed of movement of materials, information and } \\
\text { communication between different organizational structures and system components; } \\
\text { Enhance integration and coordination processes; Manufacturing and supply effortless } \\
\text { processes to make changes }\end{array}$ \\
\hline High quality and \\
product
\end{tabular}$\quad \begin{aligned} & \text { Information products and services with high added value content and content } \\
& \text { Quality of life } \\
& \text { Design right the first time } \\
& \text { Short period of development }\end{aligned}$

Source: Provided by authors.

\subsection{Conceptual Model and Research Hypotheses}

The present study is aimed in assessing effect of E-HRM on creating of organizational agility. Through studying theoretical literature of the subject (Tsourveloudiset et al., 2003; Sherehiy et al., 2007; Pouyan \& Nazari, 2009 and Anshar et al., 2009), the following hypotheses have been developed for this research.

Main hypothesis: E-HRM has significant and positive effect on creating agility in Bushehr City Banks.

\section{Secondary hypotheses:}

1- E-employment has significant and positive effect on creation of agility in Bushehr City Banks.

2- E-training has significant and positive effect on creation of agility in Bushehr City Banks.

3- E-payment of human resources has significant and positive effect on creation of agility in Bushehr City Banks.

4- E-performance appraisal of human resources has significant and positive effect on creation of agility in Bushehr City Banks.

5- E-communications of human resources has significant and positive effect on creation of agility in Bushehr City Banks. 
6- E-maintenance of human resources has significant and positive effect on creation of agility in Bushehr City Banks.

According to relationships between variables in research hypotheses of the study, conceptual model has been designed (Figure 1).

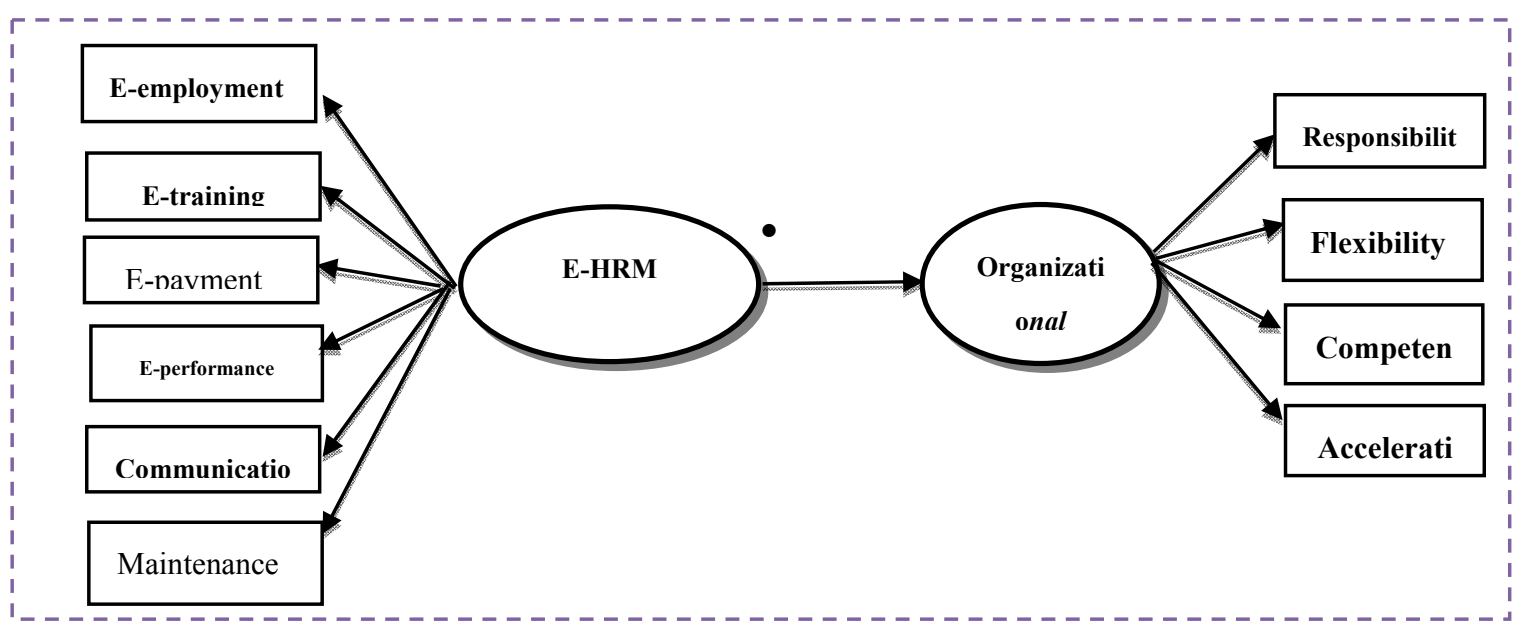

Figure 1. Conceptual model of research

\section{Research Methodology}

The present study is an applied research in terms of objective and is a descriptive-survey study in terms of data collection. Statistical population of the study includes all managers and employees of centralized Commercial banks in Bushehr. Whole statistical population includes 1684 people. Because of large size of statistical population, stratified-random sampling method has been applied. Suitable statistical sample for the study based on Cochran formula has been estimated to 313 people from limited population and with confidence level of $95 \%$ and the level of sampling error of 5\%. Through review of theoretical and empirical literature, a questionnaire was designed based on Likert scale with 52 items. The questionnaire includes 4 sections including introduction, demographic questions, E-HRM questions and organizational agility questions. For data collection purpose, the questionnaires were distributed among 350 people of managers and employees of Bushehr Banks in face to face manner, which were selected randomly based on number of employees of each bank. Afterwards, 337 questionnaires were collected. 22 questionnaires were excluded because of being fulfilled imperfectly and finally, 315 questionnaires were used and analyzed.

Validity of the questionnaire was measured using two methods of face content validity and structural validity. To measure face content validity, the questionnaire was given to a number of professors and scholars in field of management and some managers and experts of the studied population (studied banks of Bushehr) and they were asked to express their opinions about validity of the questionnaire. After collecting their opinions, some changes were done in the structured questionnaire. To measure structural validity, confirmatory factor analysis (CFA) method was applied. Obtained results from CFA indicate that factor load of all items of questionnaire is more than 0.7 and hence, the questionnaire has required validity.

To measure reliability of the questionnaire, Cronbach alpha coefficient has been applied. Table 3 presents calculated value of Cronbach alpha for studied variables.

According to Table 3, calculated Cronbach alpha for all variables is more than 0.7 . Therefore, it could be found that the designed questionnaire has required reliability. Conceptual model and research hypotheses have been also tested using structural equation modeling using Smart PLS software. 
Table 3. Calculated Cronbach alpha for studied variables

\begin{tabular}{|c|c|c|c|c|}
\hline Structure & Variable & $\begin{array}{l}\text { Number } \\
\text { of items }\end{array}$ & Item extraction source & $\begin{array}{c}\text { Calculated } \\
\text { Cronbach alpha }\end{array}$ \\
\hline \multirow{6}{*}{ E-HRM } & E- employment & 4 & $\begin{array}{l}\text { Pouyan and Nazari (2009); } \\
\text { Stone et al (2013) }\end{array}$ & 0.73 \\
\hline & E- training & 4 & $\begin{array}{l}\text { Anshar et al. (2009); } \\
\text { Dongming (2014) }\end{array}$ & 0.75 \\
\hline & E- payment & 4 & $\begin{array}{l}\text { Pouyan and Nazari (2009); } \\
\text { Anshar et al. (2009) }\end{array}$ & 0.71 \\
\hline & e- performance appraisal & 4 & \multirow{2}{*}{$\begin{array}{l}\text { Malin and Yuy (2015); David } \\
\text { (2015); Pouyan and Nazari } \\
\text { (2009) }\end{array}$} & 0.76 \\
\hline & $\begin{array}{l}\text { E- Human resource } \\
\text { communications }\end{array}$ & 4 & & 0.76 \\
\hline & $\begin{array}{l}\text { E- Human resource } \\
\text { maintenance }\end{array}$ & 4 & \multirow{6}{*}{ Sharifi and zhang (1999) } & 0.73 \\
\hline \multirow{5}{*}{$\begin{array}{l}\text { Organizational } \\
\text { agility }\end{array}$} & Acceleration & 6 & & 0.75 \\
\hline & Responsibility & 7 & & 0.82 \\
\hline & Competency & 7 & & 0.71 \\
\hline & Flexibility & 8 & & 0.83 \\
\hline & Total & 52 & & 0.87 \\
\hline
\end{tabular}

Source: Authors' findings.

\section{Data Analysis and Finding}

For purpose of data analysis, descriptive statistics have been applied to analyze demographic variables. Table 4 is related to demographic variables, which has been analyzed through collecting 315 questionnaires.

Table 4. Demographic characteristics of respondents

\begin{tabular}{ccc}
\hline Demographic variable & Levels & Frequency percent \\
\hline \multirow{2}{*}{ Gender } & Male & $87 / 3$ \\
& Female & $12 / 7$ \\
Education status & Diploma & $20 / 1$ \\
& Associate degree & $20 / 3$ \\
& Bachelor degree & $47 / 5$ \\
& Master degree and higher & $12 / 1$ \\
Age & $18-25$ years old & $4 / 1$ \\
& $26-35$ years old & $52 / 1$ \\
& $36-45$ years old & $32 / 1$ \\
The duration for use of internet banking services & Elder than 46 years old & $11 / 7$ \\
& Less than 1 year & 27 \\
& $1-3$ years & 42 \\
\end{tabular}

Source: Authors' findings.

Conceptual model and research hypotheses have been tested using structural equation modeling in Smart PLS software. Structural equation modeling helps the researcher to test and examine theoretical model formed of 
different components in both general and partial forms. Implementation of structural equation modeling indicates that there is positive and significant relationship between elements of different layers of conceptual model. Figures 2 and 3 illustrate obtained results from structural equation modeling.

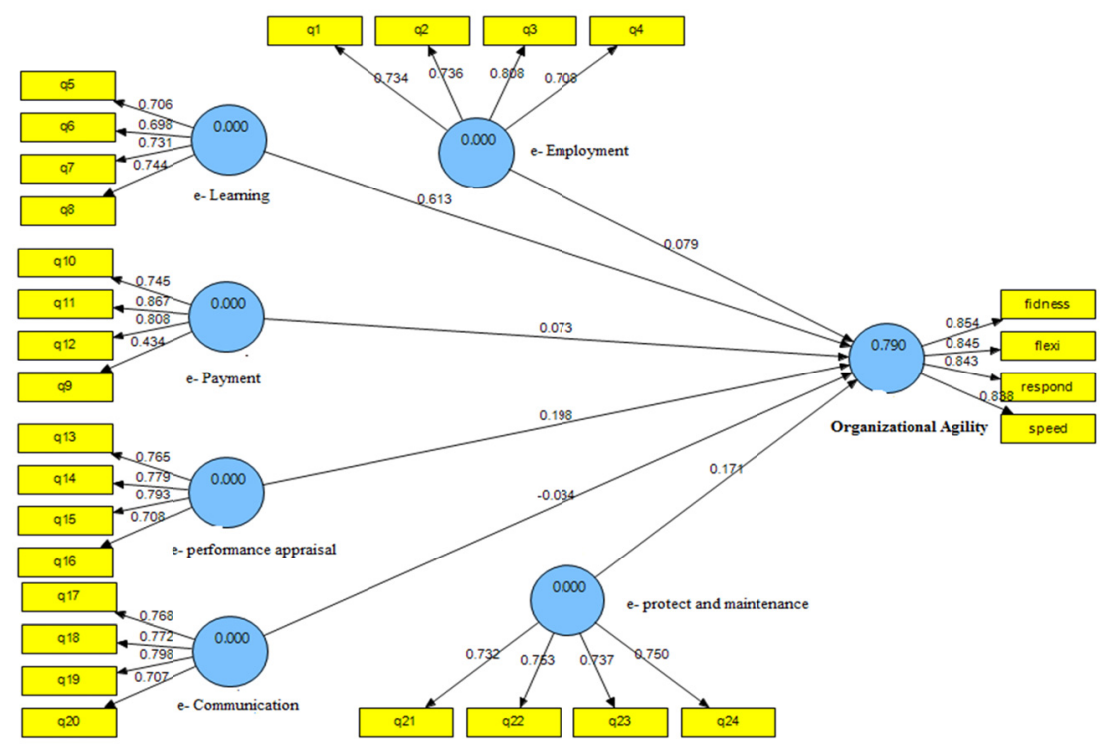

Figure 2. Implementation of structural equation model, along with standardized coefficients (path coefficient)

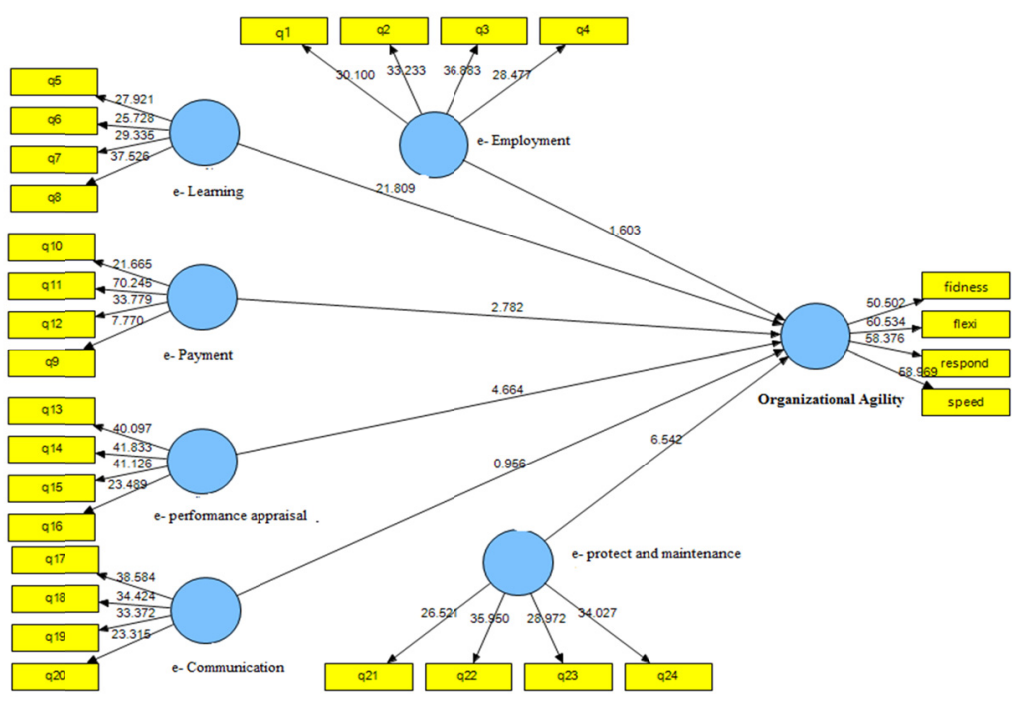

Figure 3. Implementation of structural equation model, along with significance coefficients (t-value)

Model fitness indices can be one of the most important states in structural equation modeling analysis. The indices are presented to answer the question that dose the structured model by data confirm conceptual model of the study? Obtained results from model fitness indices and evaluation of relationship between different factors of model have been presented inn Table 5 .

According to Table 5, many model fitness indices have good situation. Overall validity of model doesn't mean that all existing relations in the model are confirmed. After total model fitness, existing relations should be also tested to find that can the defined relations be confirmed? According to obtained results from data extracted from implementation of structural equation model, structure of conceptual model of the study has been confirmed. Obtained results from evaluation of model fitness indices and evaluation of the relationships between different factors of model can demonstrate this fact. Now, after extraction of structural equation model data, research 
hypotheses can be tested. Obtained results from testing main hypotheses of the study have been presented in Table 6.

Table 5. Fitness indices of conceptual model for implementation of structural equation modeling

\begin{tabular}{|c|c|c|c|c|c|c|}
\hline \multirow{4}{*}{ 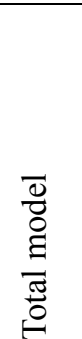 } & Hidden variable & $\begin{array}{l}\text { Average extracted } \\
\text { (AVE) }\end{array}$ & variance & $\mathrm{CR}$ & $\begin{array}{l}\text { Cronbach } \\
\text { alpha }\end{array}$ & Redun-dancy \\
\hline & E-HRM & 0.60 & & 0.89 & 0.85 & \multirow{3}{*}{0.34} \\
\hline & Organizational agility & 0.71 & & 0.90 & 0.86 & \\
\hline & $\begin{array}{l}\text { Significance level of model } \\
\text { (GOF) }\end{array}$ & $\begin{array}{l}\mathrm{R} 2=0.53 \\
\text { Communality }=0.65\end{array}$ & $0.58 \%$ & Accep & table value & \\
\hline \multirow{8}{*}{ 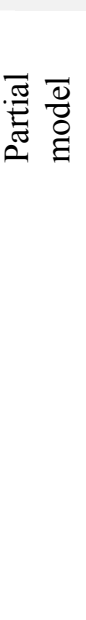 } & Hidden variables & $\begin{array}{l}\text { Average extracted } \\
\text { (AVE) }\end{array}$ & variance & $\mathrm{CR}$ & $\begin{array}{l}\text { Cronbach } \\
\text { alpha }\end{array}$ & Redun-dancy \\
\hline & E-employment & 0.55 & & 0.83 & 0.73 & \multirow[t]{7}{*}{0.62} \\
\hline & E-training & 0.51 & & 0.81 & 0.69 & \\
\hline & E-payment & 0.53 & & 0.81 & 0.70 & \\
\hline & E-performance appraisal & 0.58 & & 0.84 & 0.76 & \\
\hline & $\begin{array}{l}\text { E- Human } \\
\text { communications }\end{array}$ & 0.58 & & 0.84 & 0.75 & \\
\hline & $\begin{array}{l}\text { E- Human resource } \\
\text { maintenance }\end{array}$ & 0.55 & & 0.83 & 0.73 & \\
\hline & $\begin{array}{l}\text { Significance level of model } \\
\text { (GOF) }\end{array}$ & $\begin{array}{l}\mathrm{R} 2=0.79 \\
\text { Communality }=0.57\end{array}$ & $0.67 \%$ & \multicolumn{2}{|c|}{ Acceptable value $>0.16 \%$} & \\
\hline
\end{tabular}

Source: Authors' findings.

Table 6. Testing main research hypotheses

\begin{tabular}{|c|c|c|c|c|c|c|c|}
\hline \multirow{2}{*}{$\begin{array}{c}\text { Hypothesis } \\
1\end{array}$} & \multicolumn{3}{|c|}{ Conceptual model relations } & \multirow{2}{*}{$\begin{array}{c}\begin{array}{c}\text { Std. path } \\
\text { coefficient }\end{array} \\
0.73\end{array}$} & \multirow{2}{*}{$\begin{array}{c}\begin{array}{c}\text { Calculated } \\
\text { t-value }\end{array} \\
46.28\end{array}$} & \multirow{2}{*}{$\begin{array}{c}\text { p-value } \\
<0.01\end{array}$} & \multirow{2}{*}{$\begin{array}{c}\text { Result } \\
\text { Confirmed }\end{array}$} \\
\hline & E-HRM & $--->>$ & $\begin{array}{l}\text { Organizational } \\
\text { agility }\end{array}$ & & & & \\
\hline 2 & E-employment & $--->>$ & $\begin{array}{c}\text { Organizational } \\
\text { agility }\end{array}$ & 0.92 & 1.60 & $\geq 0.05$ & Rejected \\
\hline 3 & E-training & $---->$ & $\begin{array}{l}\text { Organizational } \\
\text { agility }\end{array}$ & 0.77 & 21.80 & $<0.01$ & Confirmed \\
\hline 4 & E-payment & $--->>$ & $\begin{array}{l}\text { Organizational } \\
\text { agility }\end{array}$ & 0.72 & 2.78 & $<0.01$ & Confirmed \\
\hline 5 & $\begin{array}{l}\text { E-performance } \\
\text { appraisal }\end{array}$ & $--->>$ & $\begin{array}{c}\text { Organizational } \\
\text { agility }\end{array}$ & 0.86 & 4.66 & $<0.01$ & Confirmed \\
\hline 6 & $\begin{array}{l}\text { E- Human resource } \\
\text { communication }\end{array}$ & $--->>$ & $\begin{array}{l}\text { Organizational } \\
\text { agility }\end{array}$ & 0.81 & 0.96 & $\geq 0.05$ & Rejected \\
\hline 7 & $\begin{array}{l}\text { E- Human resource } \\
\text { maintenance }\end{array}$ & $---->$ & $\begin{array}{l}\text { Organizational } \\
\text { agility }\end{array}$ & 0.77 & 6.54 & $<0.01$ & Confirmed \\
\hline
\end{tabular}

Source: Authors' findings.

If calculated t-value in model is more than 1.96; it means that research hypothesis has been confirmed in 
confidence level of $95 \%$. If t-value is above 2.5 , it means that hypothesis has been confirmed in confidence level of $99 \%$. According to table, all research hypotheses have been confirmed except for hypotheses 2 and 6.

\section{Conclusion and Suggestions}

As it was mentioned before, the main purpose of the study has been finding an answer for the question that how one can use HRM approach to develop organizational agility? E-HRM is a very important factor for acceleration and improvement of conducting all affairs. Continuous use of E-HRM is so important for success or failure of electronic projects. It should be mentioned that model indices include E-employment of human resources, E-training of human resources, E-payment of human resources, E-communications and E-maintenance of human resources, acceleration, responsibility, flexibility and competency.

According to obtained results from the study, it could be found that E-HRM and its subsystems can affect creation of organizational agility. The findings have been in consistence with results of previous studies and most of the relevant studies indicate direct and indirect effectiveness of E-HRM and its subsystems in creating organizational agility. Researchers such as Strohmeier and Kabst (2014); Mehrjoo and Mirmousavi (2014); Heikkil et al. (2013); Yusliza and Ramayah (2012); Huang et al (2012); Aghayi (2014); Khosravi et al. (2012); Musakhani et al. (2011) and Zanjirchi (2008) have found in their studies that new emerged procedures in science and technology have destroyed bases of previous approaches in regard with production and industrial engineering. On one hand, advancement of knowledge in fields like electronics and IT is being occurred so fast that no time remains for codification of suitable strategies for the current age and on the other hand, the advancements have made outside environment uncertain and unpredictable for the organizations. On the contrary, organizations have also overcome to some extent the problems through selecting approaches such as flexibility in production; although the approach can't be also effective. Agile thinking is an approach that can overcome almost environmental uncertainties and can have also required stability and flexibility.

Obtained results from the present study indicate that E-employment of human resources has no positive and significant effect on organizational agility. The findings have not been in consistence with results of previous studies. Studies of researchers such as Bissola and Imperatori (2014); Stone et al. (2013) and Imanipour et al. (2012) have found in their studies that E-employment of human resources can have positive effect on organizational agility. It seems that E-employment can affect organizational agility, when the organization employs people with high emotional intelligence and good in skills such as negotiation, leadership and critical thoughts. To promote agility, organization should attract people with different thoughts, so that the process of creativity and innovation can be facilitated.

Moreover, obtained results from the study indicate positive and significant effect of E-training of human resources on development of organizational agility. The results have been in consistence with findings of previous studies. Researchers such as Candy et al. (2015); Dongming et al. (2014); Miguel et al. (2010) and Imanipour et al. (2012) have found in their studies that E-training of human resources has positive and significant effect on development of agility. Using experienced professors for training personnel in groups can cost a lot; although if the training is supplied by an experienced professor to a lot of employees through electronic systems, training costs of the organization would be declined significantly. Also, more forces can be trained through this. Moreover, another possibility in the organization that can be created through implementing E-HRM in the organization is recording and putting training courses of the professors in form of electronic files. If a number of personnel fail to use them due to date, they can gain another chance to refer to these files in right time and use required trainings (Alah Gholizadeh Azari, 2010).

According to obtained results, it could be mentioned that E-payment for human resources can affect organizational agility. The result has been in consistence with findings of previous studies. Researchers like Antonio Ruiz (2015); Laura et al. (2014); Cornwall and Perlman (1990) have found in their studies that E-payment of human resources has positive and significant effect on organizational agility. Electronic rewarding and payment systems can be considered as main subsystems of E-HRM system in the organizations. Rewarding and payment system management needs considering 4 issues: good rewards, short and long-term time attitude, using various rewards and paying attention to the principle of equality. Using E-payment system, the 4 important issues would be observed better (Cornwall \& Perlman, 1990).

Another result of the study is that E-performance appraisal of human resources can have positive and significant effect on development of organizational agility. The finding is in consistence with findings of previous studies. Researchers like Malin and Youyi (2014) and Sadr Sadat (2009) have found in their studies that as improvement of productivity is one of the main goals of every organization and this is a function of improvement of performance of employees, performance appraisal of employees is an important issue in this regard. This is 
because; if appraisal system is designed in an effective manner, it can make appraisal effective for evaluation targets such as promotion, declination and payment and growing destinations such as planning. Performance appraisal processes need specific considerations due to their abundant applications and on the other hand, E-performance appraisal is so important, especially in large organizations that have a large number of members.

Also, the study indicated that E-communications of human resources have no significant and positive effect on organizational agility. The finding is not in consistence with results of previous studies. Researchers such as David et al. (2015); Sharon et al. (2014); Ferry de vit (2011); Remus (2007) and Imanipour et al. (2012) have found in their studies that to have good understanding of role of leaders in prevailing mental ability and positive results of working (job satisfaction, organizational commitment and job performance) for employees, they should be involved in e-communications in their working process. In fact, through making them be involved in the electronic processes can be in significant correlation with this issue in psychological terms; meaning that satisfaction and commitment of employees to their job would be enhanced, whereby results and outputs of their work would be also empowered.

Finally, another result of the study is that e-maintenance of human resources can have significant and positive effect on development of organizational agility. The finding is in consistence with results of previous studies. Researchers like Voermans and Veldhoven (2007); Ruël et al. (2007); Vafayinejad et al. (2013); Eskandari and Abedi (2009) have found in their studies that electronic maintenance of human resources can help improvement of value and position of employees and equipping them with more competencies and encourage them for searching more opportunities. Such use of opportunities is one of the main elements of agility. Using E-HRM, organization can have comprehensive information about all employees. Employees can also have access to their experiences and evidences and use them and even update them if necessary.

According to obtained results and research literature, some suggestions are presented for managers and the organizations as follows:

- For purpose of development of E-HRM in the organization, suitable budget should be allocated and this can be achieved just when the attitude to IT in organization has been changed and it has been considered as a strategic partner and something beyond application of backup in the organization.

- To reduce IT gap, the organization can supply some trainings adapted to it to its employees. In this regard and for purpose of providing its conditions, it would be better for the organization to use electronic training system as much as possible.

- One of the services that can be conducted through digital environment is employment process. Today, just in a few minutes using electronic technologies, a person can send employment application from the farthest points of the country for the employment center and eliminated through this many administrative stages such as to provide and proliferate primary information papers of applicants. Also, extraction and adjustment of information of people with organizational conditions and conditions of job acceptance can be conducted using automatic system of adjustment of job conditions with the employee.

- E-training of human resources is the most important variable in this study. Hence, it is suggested to managers of banks to provide suitable condition for e-training to enhance facility of access to e-training resources in the organization and also to enhance facility of sharing training content among employees.

- Maintenance of human resources plays key role in creating organizational agility. It is suggested to managers of electronic systems to offer more electronic systems to enhance updating possibility of knowledge of employees by electronic systems.

- Through proper and transparent information system using online and intelligent systems, conditions would be provided for maintenance of human resources. Therefore, it is suggested to managers to have true information system about the organization and its activities to inform employees.

- It would be better for the managers to make their payment and rewarding system electronic to make employees sure that rewards are based on performance of people and the principle of equality has been considered. In addition, when employees know that managers reward new ideas, they would certainly attempt to make ideas. Paying tangible and perceivable rewards can be the best way for gaining attention and trust of employees to managers and idea making.

- It is suggested to managers to provide E-HRM systems with no error for the employees. In addition, E-payment systems should be designed in a manner that they can minimize banking operations and also 
with access of human resources to internet banking of salary and payment, they can accelerate bank payment system.

- It would be better for the managers to investigate working quality of employees based on e-performance appraisal systems to enhance efficiency of bank affairs.

- It is suggested to managers to establish electronic systems of controlling entrance and exit of human resources in banks. Controlling entrance and exit time can cause integration of banking affairs. In addition, recoding and managing leave and advance money using computer systems can reduce time waste resulted from its traditional method. Hence, through using electronic recording of work activities of employees daily, performance appraisal can be accelerated.

\section{Limitations of the Study}

Studies constantly have some limitations that can affect results of the study and decline its generalizability and reliability. The present study is not also an exception. For example, data collection of the study has been questionnaire. Questionnaire has some defects as a data collection instrument, which can affect the results. In addition, some studied organizations don't use E-HRM and hence, their managers and experts may have no proper perception of E-HRM. Hence, this can affect fulfillment of the questionnaire.

\section{References}

Aghayi, M. (2014). Presenting a conceptual model of organizational agility. Journal of Technology Growth, 10(3), 37-43. (In Persian)

Alah Gholizadeh, M., \& Omumi, R. (2010). Eeffect of IT on tasks and activities of human resource managers in organizations. Journal of Human Resource Management, 2(3), 87-103. (In Persian)

Antonio Ruiz, M. (2015). Towards a web payment framework: State-of-the-art and challenges. Electronic Commerce Research and Applications, 14(5), 345-350. http://dx.doi.org/10.1016/j.elerap.2015.08.003

Ardakani, S., Konjkav Monfared, A., Hakaki, M., \& Rezaei Dolat Abadi, H. (2013). Identification of effective factors in individual innovation development. Journal of Technology Development Management, 1(2), 135-155. (In Persian)

Armey, E., Lipow, J., \& Webb, J. (2014). The impact of electronic financial payments on crime. Information Economics and Policy, 29, 46-57. http://dx.doi.org/10.1016/j.infoecopol.2014.10.002

Bissola, R., \& Imperatori, B. (2014). The unexpected side of relational e-HRM Developing trust in the HR department. Employee Relations, 36(4), 376-397. http://dx.doi.org/10.1108/ER-07-2013-0078

Braunscheidel, M., \& Suresh, N. (2009). The organizational antecedents of a firm's supply chain agility for risk risk mitigation and response. Journal of Operational Management, 27, 119-140. http://dx.doi.org/10. 1016/j.jom.2008.09.006

Candy, K., Weiling K., \& Hefu, L. (2015). Choice decision of e-learning system: Implications from construal level theory. Information \& Management, 52(2), 160-169. http://dx.doi.org/10.1016/j.im.2014.07.003

Cornwall, J., \& Perlman, B. (1990). Organizational entrepreneurship. Richard Irwin publication.

Dobrzykowski, D., \& Tarafdar, M. (2015). Understanding information exchange in healthcare operations: Evidence from hospitals and Patients. Journal of Operations Management, 36, 201-214. http://dx.doi.org/ 10.1016/j.jom.2014.12.003

Dolan, S. H., \& Schuler, R. (2010). Management of employee affairs. Trans. M. A. Toosi, \& M. Saebi (2009). Tehran: Public Management Education Center. (In Persian)

Eskandari, M., \& Abedi, A. (2009). Assessing relevant factors of maintenance of employees in Armed Forces of Islamic Republic of Iran. Journal of Human Resource Management, 1(2), 107-125. (In Persian)

Farsijani, H. (2011). Identification of effective components in organizational agility in universities. Business Management Perspective, 14, 13-27. (In Persian)

Ferry de Wit, M. (2011). A review of the literature on factors and consequences of e-HRM success and a contingency framework. Wilmington, DE Mercy College Master of Science in Human Resource Management.

Ganguly, A., Nilchiani, R., \& Farr, J. (2009). Evaluating agility in corporate enterprises. International Journal of Production Economics, 118, 410-423. http://dx.doi.org/10.1016/j.ijpe.2008.12.009 
Heikkila, F. (2013). An institutional theory perspective on e-HRM's strategic potential in MNC subsidiaries. The Journal of Strategic Information Systems, 22, 238-251. http://dx.doi.org/10.1016/j.jsis.2013.07.003

Henson, R. (2008). The Next Decade of HR: Trends, Technologies, and Recommendations, In Greutal and Stone, The Brave New World of EHR San Francisco, CA: Jossey-Bass, pp. 255-292.

Hosseini, A., Hadizadeh Moghaddam, A., \& Javadi, H. (2011). Assessing role of resource management in effectiveness of HRM (pp. 212-223). Fifth International Conference on E-HRM, Tehran. (In Persian)

Huang, P., Ouyang, T., Pan, Sh., \& Chou, T. (2012). The role of IT in achieving perational agility: A case study of Haier. China. International Journal of Information Management, 32, 294-298. http://dx.doi.org/10.1016/j.ijinfomgt.2012.02.001

Imanipour, N., Mohammadpour, S., \& Gholipour, A. (2012). Role of E-HRM in organizational innovation. Journal of Entrepreneurship Development, 52, 87-105. (In Persian)

John. B., Knowles, D., Francis, D., \& Mered, S. (2001). The Developing the agile manufacturing, The 21'st Century competitive strategy (pp. 123-140). Elsevier Science Ltd.

Khosravi, A. (2012). Identification of empowerment factors of human resource agility using Delphi Method in electronic industries. Journal of Management Improvement, 6(4), 129-153. (In Persian)

Mehrjoo, D., \& Mirmoosavi, M. (2014). Electronic System of Human Resource Management and Exercise of Leadership in Human Resources: A Case Study of Amiralmomenin Hospital of Arak City, Iran. International Journal of Economy, Management and Social Sciences, 3(4), 243-246.

Musakhani, M., Manian, A., Hasangholipour, T., Mirbaha, A., \& Abtin, A. (2011). Presenting a model for E-HRM development in Iran's public organizations. General Management Studies, 4(2), 41-62. (In Persian)

Nazari, G. H., \& Pouyan, S. (2009). E- Human Resource Management. Tehran: Shalak Press. (In Persian)

Olivas-Lujan, R., \& Zapata-Cantu, L. (2007). E-HRM in Mexico: Adapting innovations for global competitiveness, International Journal of Manpower, 28(5), 418-434. http://dx.doi.org/10.1108/0143772 0710778402

Pan, F., \& Nagi, R. (2010). Robust supply chain design under uncertain demand in agile manufacturing. Computers \& Operations Research, 37(4), 668-683. http://dx.doi.org/10.1016/j.cor.2009.06.017

Remus, U. (2007). Critical success factors for implementing enterprise portals: A comparison with ERP implementations. Business Process Management Journal, 15, 538-552. http://dx.doi.org/10.1108/14637150 710763568

Ruël, H., Bondarouk, T., \& Looise Kees, J. (2004). E-HRM: Innovation or Irritation. An Explorative Empirical Study in Five Large organization. Management Revue, 15(3), 364-380.

Ruta, C. (2005). The application of change management theory to the HR portal implementation in subsidiaries of multinational corporations. Human Resource Management, 44(1), 35-53. http://dx.doi.org/10.1002/hrm. 20039

Sadr Sadat, A. (2009). Presenting a model for effective performance appraisal of employees of Iran National Oil Co. Journal of Human Resource Management in Oil Industry, 3, 92-117. (In Persian)

Salami, M., Zareimatin, H., Vazin, M., \& Jandaghi, G. H. (2013). Assessing the status of effective factors in organizational agility in Broadcast Organizations. Academic Journal of Organizational Culture Management, 11(2), 117-132. (In Persian)

Sharifi, H., \& zhang, Z. (1999). A methodology for achieving agility in manufacturing organization: an introduction. International Journal of Production Economics, 62, 7-22.

Sharon H., Hyeung Kang, J., \& Gu Seo, M. (2014). The interactive effect of leader-member exchange and electronic communication on employee psychological empowerment and work outcomes. The Leadership Quarterly, 25(4), 772-783. http://dx.doi.org/10.1016/j.leaqua.2014.04.006

Sherehiy, B., Karwowski, W., \& Layer, K. (2007). A review of enterprise agility: Concepts, frameworks and attributes. International Journal of Industrial Ergonomics, 37, 445-460. http://dx.doi.org/10.1016/j.ergon. 2007.01.007

Song, M., \& Guan, Y. (2015). The electronic government performance of environmental protection administrations in Anhui province, China. Technological Forecasting and Social Change, 96, 79-88. http://dx.doi.org/10.1016/j.techfore.2014.10.001 
Srivastava, S. (2010). Shaping Organization with e-HRM, International Journal of Innovation, Management and Technology, 1(1), 87-104. Retrieved from http://www.ijimt.org/papers/10-M416\%20p.pdf

Stone, L., \& Lukaszewski, M. (2009). An expanded model of the factors affecting the acceptance and effectiveness of electronic human resource management systems. Human Resource Management Review, 19(3), 134-143. http://dx.doi.org/10.1016/j.hrmr.2008.11.003

Stone, L., Kimberly, M., Lukaszewski, F., Stone-Romero, F., \& Johnson, L. (2013). Factors affecting the effectiveness and acceptance of electronic selection systems. Human Resource Management Review, 23(1), 50-70. http://dx.doi.org/10.1016/j.hrmr.2012.06.006

Strohmeier, S. (2007). Research in e-HRM: Review and implication. Human Resource Management Review, 17(1), 19-37. http://dx.doi.org/10.1016/j.hrmr.2006.11.002

Strohmeier, S., \& Kabst, R. (2014). Organizational adoption of e-HRM in Europe An empirical exploration of major adoption factors. Journal of Managerial Psychology, 24(6), 482-501. http://dx.doi.org/10.1108/02 683940910974099

Tsourveloudis, N., Valavanis, K., Gracanin, D., \& Matijasevic, M. (2003). On the Measurement of Agility in Manufacturing Systems. Journal of Intelligent and Robotic Systems, Kluwer Academic Publishers Hingham, 33(3), 329-342. Retrieved from http://citeseerx.ist.psu.edu/viewdoc/download?doi=10.1.1.92.1215\&rep= rep1\&type $=$ pdf

Vafayinejad, N., Heydari Gorji, A., \& Nadighara, A. (2013). Assessing effective factors in survival of administrative employees of Department of Resources Management of Medical Sciences in Mazandaran. Engineering Journal of Farayandha (processes), 19, 97-117. (In Persian)

Voermans M., \& Veldhoven, M. (2007). Attitude towards EHRM: an empirical study at Philips. Personnel Review, 36(6), 887-902. http://dx.doi.org/10.1108/00483480710822418

Xu, D. M., Huang, W., Wang, H., \& Heales, W. (2014). Enhancing e- learning effectiveness using an intelligent agent- supported personalized virtual learning environment: An empirical investigation. Information \& Management, 51(4), 430-440. http://dx.doi.org/10.1016/j.im.2014.02.009

Yaghoubi, N., \& Rahat Dahmardeh, M. (2010). Analytical approach to effective factors on organizational agility. Journal of Basic and Applied Scientific Research, 7(9), 62-81.

Yusliza, M., \& Ramayah, T. (2012). Determinants of attitude towards E-HRM: an empirical study among HR professionals. Mylizia International Conference on Asia Pacific Business Innovation and Technology Management.

Zanjirchi, A. (2008). A model for organizational agility for Iran's Electronic Industry (PhD thesis). Tehran: Allameh Tabatabayi niversity. (In Persian)

Zare Elmi, N. (2011). Assessing effect of using E-HRM system on performance of Financial and Credit Institute of Mehr in Lorestan Province (BSC approach) (MA thesis). Sistan and Baluchistan University. (In Persian)

\section{Copyrights}

Copyright for this article is retained by the author(s), with first publication rights granted to the journal.

This is an open-access article distributed under the terms and conditions of the Creative Commons Attribution license (http://creativecommons.org/licenses/by/3.0/). 